\title{
SOME FACTORS INFLUENCING THE RESULTS OF CONCEPTION IN COWS AND HEIFERS IN ESTRUS SYNCHRONIZED BY THE SYNTHETIC ANALOGUE OF PGF PL $_{2 \alpha}$ CLOPROSTENOL
}

\author{
A. VINKLER, E. KUDLÁČ, A. JIŘ́ǏEK \\ Department of Reproduction of Farm Animals and Surgery, University of Veterinary Science, \\ 61242 Brno, \\ District Veterinary Service Centre, Gottwaldov
}

Received March 25, 1981

\begin{abstract}
Vinkler A., E. Kudláč, A. Jiříček: Some Factors Influencing the Results of Conception in Cows and Heifers in Estrus Synchronized by the Synthetic Analogue of $P G F_{2 \alpha}$ Cloprostenol. Acta vet. Brno, 51, 1982: 81-89.

A study of the contribution of the breeding bull, the work of the operator and the influence of the size of the synchronized group on the conception rate in breeding cows after a first insemination at estrus, synchronized by cloprostenol, in 21 groups of heifers, of 469 head, and 21 groups of cows ( 350 head), has shown that:

1. Conception rate in breeding cows after a first insemination during synchronized estrus was significantly influenced by the use of a bull allotted according to a mating plan. After insemination of the breeders, carried out with frozen semen from various bulls, statistically highly significant differences in conception after the lst insemination $(P<0.01)$ were ascertained.

2. The conception rate in breeding cows after a lst insemination were influenced by the work of the operators. Amongst the individual techniques, statistically highly significant differences $(P<0.01)$ were found in the attained conception.

3. Conception rates in breeding cows were also strikingly influenced by the size of the synchronized group. A decrease in conception of $18 \%$ (at the limit of statistical significance) was ascertained after a lst insemination when there were more than 30 heifers in the synchronized group, and a statistically highly significant decrease of $25 \%(P<0.01)$ was found when there were more than 40 heifers to a group in inseminations carried out by a sole operator. In cows a decrease of $8 \%$ in a conception was found after a first insemination in groups with a number of breeders larger than 40 head.
\end{abstract}

Synchronization of estrus, prostaglandins, factors influencing conception, ability to conceive.

Prostaglandins (PG) are remarkably effective materials, similar to hormones, naturally occurring in many tissues of the organism, and possessing specific biological properties (Kudláč et al. 1977). According to the dissimilarity in structural arrangement and biological effect, they are divided into four groups - A, B, E and F. In regard to reproduction they are in close relation to processes of reproduction in the PG groups $\mathrm{E}$ and $\mathrm{F}$ and especially $\mathrm{PGF}_{2} \alpha$. Their most important component besides the uterotonic effect, is their ability to influence the morphology and function of the corpus luteum, and they also bring about its rapid regression and the cessation of progesterone production (Kudláč 1976, Kudláč et al. 1977).

The first paper on the luteolytic effect of $\mathrm{PGF}_{2 \alpha}$ was submitted by Rowson et al. (1972), Liehr et al. (1972) and Lauderdale (1972). After intrauterine application of $0.5-1 \mathrm{mg}$ PGF $_{2 \alpha}$ the extinction of corpus luteum, and an obvious estrus took place within $2-4$ days. Lou is et 
al. (1974) and Lauderdale et al. (1974) reported that after applying 25-30 mg PFG $\alpha$ i. m., s. c., and intravaginally, they obtained the same result. Binder et al. (1974) published a paper on the synthesis of 16-aryloxprostaglandins, of which several have a strong luteolytic effect. An example of these materials are the preparations of the English firm ICI, originally termed ICI 79939 and ICI 80996 . Cooper (1974) demonstrated that $0.5 \mathrm{mg}$ of the material ICI 80996 , applied i. m. to cattle, is sufficient to cause a luteolytic effect.

Cooper and Furr (1974), Lamming et al. (1975), Elving et al. (1975), Moore (1975), Hafs (1976), Kudláč et al. (1977, 1978, 1979) agreed that treatment with PG and their synthetic analogues is completely ineffective in cows with developing corpus luteum during the first $4-5$ days of the cycle. Nor has it any influence, when spontaneous regression of the corpus luteum has taken place. They recommend the use of PG and their synthetic analogues only in animals with an easily palpable corpus luteum, corresponding to the 6th -16 th or 18th day of the cycle. In an attempt to bridge the period of the cycle, when the corpora lutea on the ovarium are not sensitive to the application of PG, and to avoid the necessity of controlling the state of the ovaries in cycling animals, Cooper (1974), Hafs et al. (1975) have recommended treatment twice in succession within $10-12$ days.

The first to report the use of cloprostenol for synchronization of estrus in heifers in this country were Kudláč et al. (1977), Podaný et al. (1976), Fulka et al. (1978) and others. Kudláč et al. (1977) confirmed the great effectiveness of cloprostenol for the provocation of estrus in heifers during the period, when there is an easily detectable corpus luteum on one of the ovaries, $i$. e. from the 6 th to the 16th or the 18th day of the cycle. The onset of estrus was ascertained as early as $48 \mathrm{hrs}$ in some animals, in majority of cows within $60-72 \mathrm{hrs}$. It was externally recognizable, and lasted $24-36 \mathrm{hrs}$ in most animals. Ovulation during estrus, caused by cloprostenol, usually took place within 84-108 hrs after treatment, i. e. during 2 days of estrus. After a second application of cloprostenol a maturing Graafian follicle was found on one of the ovaries, 2-3 days after treatment in $90.79 \%$ animals. In one insemination after application of cloprostenol, a conception rate of $44.44 \%$ was attained after a first insemination. After insemination within $70 \mathrm{hrs}$ and reinsemination within $90 \mathrm{hrs}$, pregnancy was attained in $52.5 \%$ after a first insemination. After testing one application of cloprostenol in heifers on the 6th to the 16th day of the cycle, and in frontal insemination $72 \mathrm{hrs}$ after the application of cloprostenol, and reinsemination $8-12 \mathrm{hrs}$ later, $60 \%$ pregnancy was attained after a first insemination. Fulka et al. (1978) reported that the results of conception in synchronized estrus are also influenced by the level of nutrition. In heifers on a low plane of nutrition $38.4 \%$ conceived after a first insemination, $67.3 \%$ well-nourished heifers became pregnant after a first insemination. In the control group without any synchronization of estrus $72.0 \%$ animals conceived after a lst insemination.

In $1979 \mathrm{Kudláć}$ et al., and in $1980 \mathrm{Kudláč} \mathrm{and} \mathrm{Vinkler} \mathrm{reported} \mathrm{the} \mathrm{use} \mathrm{of} \mathrm{cloprostenol} \mathrm{for}$ synchronization of estrus in cows. They pointed out some differences, which need to be taken into account in the synchronization of estrus in cows. During the basic gynecological examination they ascertained pathological conditions and functional defects in $23.8 \%$ cows that required treatment, and these cows were unsuited for synchronization. A further $25.34 \%$ cows were at the stage of proestrus, estrus and early metestrus, and were thus also unsuitable for the application of PG. A mere $50.82 \%$ cows were in the period of the 6th-18th day of the cycle. In $99.72 \%$ cows estrus appeared within 3-4 days after application of PG. A control examination within 10-12 days after use of PG evidenced estrus as complete and ovulation resulted in $88.0 \%$ cows. Conception after a lst insemination reached a mean of $54.87 \%$ in synchronized estrus in a period of one year. The total percentage of pregnancies in synchronized cows was $77.22 \%$ during 17.95 days from the beginning of the experiment, with an insemination index of 1.44 .

It was found that the conception of cows in synchronized estrus was only slightly influenced by age, but it was appreciably influenced by the stage of the sexual cycle when cloprostenol was applied, and the season also exerted a marked influence. The worst results were reached during the winter months, the best in autumn. Conception improved in cows with prolonged postpartum period. Pregnancy after a first insemination was diagnosed in $63.24 \%$ loose-housed cows but only $49.53 \%$ cows held in stanchion type barns.

From the presented literary review it is to be seen that close attention has been paid to the elucidation of the causes that influence the attained fertility in synchronized estrus of breeding cows, eventually the influence of nutrition, housing, and the season on the attained conception. The evaluation of the information showed that there must be a number of other factors affecting the results. In available literature no exact data as to what degree the results may be influenced by the semen of the employed bulls, the work of the operator, eventually by the number of animals in the synchronized group. Therefore we have directed our attention to this problem. 


\section{Materials and Method}

A study of the effect of breeding bulls on the conception of breeding cows after a lst insemination in synchronized estrus was carried out in 21 groups of heifers totalling 469 head on the 7 farms of one concern in the northern district of Moravia, and in two establishments, as well as in 12 groups of cows numbering 350 head on a large-scale cattle farm in a southern district of Moravia. The heifers were Bohemian Pied, Black Pied, Lowland and crossbred Czech Pied $\mathbf{x}$ Ayrshire, and Cheshire $\times$ CN, well-nourished, aged 16-20 months, corresponding in bulk to the types of cattle bred in the country. A part of the heifers was loose-housed, others were held in stanchion type barns.

The majority of the cows were black-spotted lowland and crossbred $\mathrm{CN}$ with Cheshire $\left(\mathrm{F}_{1}\right.$ and $F_{11}$ ), a smaller number being Bohemian Pied. The cows were held in a large-scale cattle farm in groups of 60 head in compartments with grated stands and raised box beds. A part of the first pregnant heifers was kept in traditional stanchion type barns.

Frozen ejaculates in pellets from 13 bulls, specified with the state record NOM-7, NOM-9, NOM-14, NEED-4, LOM-164, NEB-7, NF-11, NF-23, NX-19, MO-350, JUN-186, PX-352, $\breve{Z}-48$, were employed in the insemination of heifers.

Frozen ejaculates from 7 bulls specified by the state record NX-19, NX-41, NEB-7, RAK-25, RK-78, LM-88, were employed in the insemination of cows.

All animals were healthy and came from herds free of infections.

Before carrying out the synchronization of estrus, all breeder animals underwent a gynecological examination. Animals with a pathological finding on the sexual organs were discarded.

The synchronization of estrus was carried out in heifers according to the method reported by Kudláč et al. (1979), the synchronization of estrus in cows according to the method employed by Kudlác and Vinkler (1980).

When studying the contribution of the operator to the results of conception in the breeders in synchronized estrus with the help of cloprostenol, a comparison of the results atteined by three operators in heifers and five techniques in cows, was carried out. In all breeders in which the contribution of the operator was studied, the control of ovulation during $10-12$ days after application of cloprostenol, was also carried out.

Evaluation of the influence of the size of the synchronized group of breeders on the conception rate after a lst insemination was done in 20 groups of heifers and 11 groups of cows.

Pregnancy was ascertained by rectal palpation $45-60$ days after insemination.

The results were statistically evaluated according to Student's t-test.

\section{Results and Discusion}

The first study of the contribution of the breeding bull and the influence of some factors on the results of conception in breeders after a first insemination was carried out with heifers and later with cows. The results are presented and evaluated in this paper.

The gravidity attained after a first insemination in heifers after inseminations by semen from 13 bulls in estrus synchronized by cloprostenol, was from 15.3 to $90 \%$ (Table la). The results were extremely varied and statistical evaluation also showed that from bull No 5 with an attained fertility of $73.19 \%$ and from bull No 10 with a fertility of $52.38 \%$ they were statistically highly significant $(P<$ $<0.01$ ) on both sides. Also further statistical evaluation beyond the range defined by these two bulls, showed that the differences are at the limit of statistical significance $(P<0.10)$ to highly significant $(P<0.01)$. These results, achieved with synchronization of estrus in heifers, were compared with the results of fertility in bulls after a lst insemination by natural mating, taken from the statistics of breeding under field conditions, where the fertility of these bulls fluctuated within the limits of 44.14 to $59.67 \%$. When comparing conception rates after a first insemination carried out in synchronized estrus with heifers, and under field conditions, it was found that greater fertility was attained with the ejaculates from 10 bulls and lower fertility with the ejaculates from 3 bulls in synchronized estrus with heifers. If we take into account the widely-known fact 
that conception in heifers after a lst insemination is on the average $10-15 \%$ greater than in cows (Kudláč et al. 1977), very good results were attained in synchronized estrus in heifers with the first five bulls (NOM-7, NOM-14, NEED-4, LOM-164 and NOM-9), where conception rate after a lst insemination in synchronized estrus was 16 to $31 \%$ greater than with current procedure. In 3 other bulls (NEB-7, NF-11, NX-19) the fertility was comparable, in two ( $\breve{Z}-48$ and MO-550) as in 3 bulls (JUN-186, PY-352 and NF-23), it was worse. The low conception rates attained with the bulls PY-352 and NF-23 after inseminations carried out at the same time by one operator in one barn are especially surprising. The explanation that the differences are a result of the small number of inseminated animals might be acceptable in bulls NOM-14 and NF-11, but in the other bulls, groups of animals are comparable, and thus it is necessary to seek a different explanation.

Conception after a first insemination in cows following inseminations with semen from 7 bulls in estrus synchronized by cloprostenol was variable as it was in heifers, and the difference in the attained conception from bull LM-88 with the best fertility (67.74\%), and the bull with the worst fertility after a first insemination NEB-7 (47.5\%), was $20 \%$, even though this and other differences between the bulls were not significant. Also the comparison of the conception rate after a first insemination in synchronized estrus with routine procedures, showed significant differences.

Contribution of the bull to the conception rate in breeders is evidenced in Table $1 \mathrm{~b}$, where the results reached by one operator following inseminations with se-

Table 1a

Pregnancy after a 1st insemination attained in heifers and cows in estrus synchronized by cloprostenol after insemination carried out with the semen of various bulls

\begin{tabular}{|c|c|c|c|c|c|c|}
\hline & \multirow{2}{*}{ Bull no. } & \multirow{2}{*}{$\begin{array}{l}\text { Bull } \\
\text { registration No. }\end{array}$} & \multirow{2}{*}{$\begin{array}{c}\text { Inseminated } \\
\text { head }\end{array}$} & \multicolumn{2}{|c|}{$\begin{array}{l}\text { Conceived after } \\
\text { 1st insemination }\end{array}$} & \multirow{2}{*}{$\begin{array}{c}\text { Statistical } \\
\text { significance }\end{array}$} \\
\hline & & & & head & $\%$ & \\
\hline \multirow[t]{2}{*}{ 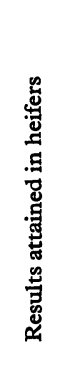 } & $\begin{array}{r}1 \\
2 \\
3 \\
4 \\
5 \\
6 \\
7 \\
8 \\
9 \\
10 \\
11 \\
12 \\
13\end{array}$ & $\begin{array}{l}\text { NOM-7 } \\
\text { NOM-14 } \\
\text { NEED-4 } \\
\text { LOM-164 } \\
\text { NOM-9 } \\
\text { NEB-7 } \\
\text { NF-11 } \\
\text { NX-19 } \\
\mathrm{Z}-48 \\
\text { MO-550 } \\
\text { JUN-186 } \\
\text { PY-352 } \\
\text { NF-23 }\end{array}$ & $\begin{array}{r}20 \\
7 \\
20 \\
34 \\
97 \\
86 \\
10 \\
18 \\
39 \\
84 \\
24 \\
17 \\
13\end{array}$ & $\begin{array}{r}18 \\
6 \\
17 \\
25 \\
71 \\
61 \\
7 \\
12 \\
23 \\
44 \\
12 \\
6 \\
2\end{array}$ & $\begin{array}{l}90.00 \\
85.70 \\
65.00 \\
73.50 \\
73.19 \\
70.90 \\
70.00 \\
66.67 \\
58.80 \\
52.38 \\
50.00 \\
35.30 \\
15.30\end{array}$ & \multirow[t]{2}{*}{ 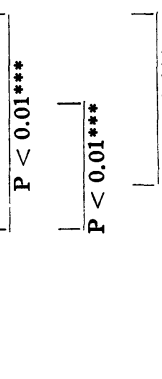 } \\
\hline & Total & & 469 & 304 & 64.82 & \\
\hline \multirow{2}{*}{ 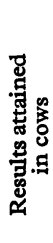 } & $\begin{array}{l}1 \\
2 \\
3 \\
4 \\
5 \\
6 \\
7\end{array}$ & $\begin{array}{l}\text { LM-88 } \\
\text { NEB-6 } \\
\text { NX-19 } \\
\text { NX-41 } \\
\text { RAK-25 } \\
\text { R R-78 } \\
\text { NEB-7 }\end{array}$ & $\begin{array}{r}31 \\
15 \\
109 \\
85 \\
15 \\
15 \\
80\end{array}$ & $\begin{array}{r}21 \\
9 \\
64 \\
46 \\
8 \\
8 \\
38\end{array}$ & $\begin{array}{l}67.74 \\
60.00 \\
58.71 \\
54.11 \\
53.33 \\
53.33 \\
47.50\end{array}$ & \multirow[t]{2}{*}{ | } \\
\hline & Total & & 350 & 194 & 55.42 & \\
\hline
\end{tabular}


Table 1b

Pregnancy after a first insemination attained in cows in estrus synchronized by cloprostenol after inseminations carried out by one operator with the semen various bulls

\begin{tabular}{|c|c|c|c|c|}
\hline \multirow{2}{*}{$\begin{array}{c}\text { Bull registration } \\
\text { No. }\end{array}$} & \multirow{2}{*}{$\begin{array}{c}\text { Inseminated } \\
\text { head }\end{array}$} & \multicolumn{2}{|c|}{$\begin{array}{l}\text { Conceived after } \\
\text { 1st insemination }\end{array}$} & \multirow{2}{*}{$\begin{array}{c}\text { Statistical } \\
\text { significance }\end{array}$} \\
\hline & & head & $\%$ & \\
\hline $\begin{array}{l}\text { NX-19 } \\
\text { NX-41 } \\
\text { NEB-7 } \\
\text { LM-88 } \\
\text { NEB-6 } \\
\text { RAK-25 } \\
\text { RR-78 }\end{array}$ & $\begin{array}{l}90 \\
37 \\
80 \\
23 \\
15 \\
15 \\
11\end{array}$ & $\begin{array}{r}50 \\
23 \\
38 \\
16 \\
9 \\
6 \\
6\end{array}$ & $\begin{array}{l}55.55 \\
62.16 \\
47.50 \\
69.56 \\
60.00 \\
50.00 \\
54.54\end{array}$ & 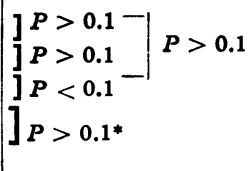 \\
\hline Total & 268 & 148 & 52.22 & \\
\hline
\end{tabular}

men from various bulls, are recorded, when the conception rate after a first insemination varied from 47.5 to $63.6 \%$ or from 50.0 to $69.6 \%$ after elimination of cows and heifers with disturbances of ovulation.

This study has shown that the conception rate after a first insemination in estrus, synchronized by cloprostenol, may be greatly influenced by bulls ranged according to the mating plan. The differences ascertained between the individual bulls were highly significant $(P<0.01)$.

Besides the contribution of the breeding bull on conception rate in breeding cows after a first insemination, the effect of the operator is given in Tables $2 \mathrm{a}$ and $2 \mathrm{~b}$. The results attained in heifers by three operators were $26.67 \%, 52.63 \%$ and $66.67 \%$, and the differences between operators $A$ and $C$ were significant $(P<0.05)$, those between operators $B$ and $C$ were highly significant $(P<0.01)$. Also the results in cows showed differences between the individual operators, even though one must not forget the relatively small number of inseminated animals. However, one must also bear in mind that the breeders were gynecologically very thoroughly examined, before being included in the experiment, and control of ovulation was carried out. Table $2 b$, where the results achieved by 4 operators after insemina-

Table 2a

Influence of the work of the operator on the conception rate after a 1st insemination in estrus synchronized by cloprostenol

\begin{tabular}{|c|c|c|c|c|c|c|}
\hline & \multirow{2}{*}{ Operator } & \multirow{2}{*}{$\begin{array}{l}\text { Insemina- } \\
\text { ted head }\end{array}$} & \multicolumn{2}{|c|}{$\begin{array}{l}\text { Conceived after } \\
\text { 1st insemination }\end{array}$} & \multirow{2}{*}{\multicolumn{2}{|c|}{ Statistical significance }} \\
\hline & & & head & $\%$ & & \\
\hline $\begin{array}{l}\text { Results } \\
\text { attained } \\
\text { in heifers }\end{array}$ & $\begin{array}{l}\text { A } \\
\text { A } \\
\mathbf{B} \\
\mathbf{C}\end{array}$ & $\begin{array}{l}51 \\
57 \\
18 \\
30\end{array}$ & $\begin{array}{r}26 \\
30 \\
12 \\
8\end{array}$ & $\begin{array}{l}50.98 \\
52.63 \\
66.67 \\
26.67\end{array}$ & $\begin{array}{l}]^{P}>0.1 \\
\text { ] }>0.1 \\
P<0.01^{* * *}\end{array}$ & $P<0.05^{* * *}$ \\
\hline $\begin{array}{l}\text { Results } \\
\text { attained } \\
\text { in cows }\end{array}$ & $\begin{array}{l}\mathbf{D} \\
\mathbf{B} \\
\mathbf{E} \\
\mathbf{F} \\
\mathbf{G} \\
\mathbf{D}\end{array}$ & $\begin{array}{l}24 \\
15 \\
19 \\
15 \\
39 \\
31\end{array}$ & $\begin{array}{r}14 \\
10 \\
10 \\
5 \\
25 \\
18\end{array}$ & $\begin{array}{l}58.33 \\
66.67 \\
52.63 \\
33.33 \\
64.10 \\
58.06\end{array}$ & $\begin{array}{l}]_{P}>0.1 \\
] P>0.1 \\
]_{P}>0.1\end{array}$ & $P<0.1^{*}$ \\
\hline
\end{tabular}


Table 2b

Pregnancy after a 1st insemination in cows synchronized by cloprostenol after inseminations carried out with semen from one bull by several operators

\begin{tabular}{|c|c|c|c|c|}
\hline \multirow{2}{*}{ Operator } & \multirow{2}{*}{$\underset{\text { head }}{\text { Inseminated }}$} & \multicolumn{2}{|c|}{$\begin{array}{l}\text { Conceived after } \\
\text { a 1st insemination }\end{array}$} & \multirow{2}{*}{ Statistical significance } \\
\hline & & head & $\%$ & \\
\hline $\begin{array}{l}\text { D } \\
\text { E } \\
\text { F } \\
\text { G }\end{array}$ & $\begin{array}{r}37 \\
17 \\
9 \\
21\end{array}$ & $\begin{array}{r}23 \\
9 \\
2 \\
12\end{array}$ & $\begin{array}{l}62.16 \\
52.94 \\
22.22 \\
57.14\end{array}$ & $\begin{array}{l}] P>0.1 \\
] P>0.1 \\
] P<0.1\end{array}-P>0.1-P<0.05$ \\
\hline Total & 84 & 46 & 54.76 & \\
\hline
\end{tabular}

Table 3

Influence of the size of the group of heifers and cows inseminated frontally in synchronized estrus with cloprostenol, on the conception rate after a 1st insemination

\begin{tabular}{|c|c|c|c|c|c|c|}
\hline & \multirow{2}{*}{\multicolumn{2}{|c|}{$\begin{array}{l}\text { Number of head } \\
\text { in group }\end{array}$}} & \multirow{2}{*}{$\begin{array}{c}\text { Inseminated } \\
\text { head }\end{array}$} & \multicolumn{2}{|c|}{$\begin{array}{l}\text { Conceived after } \\
\text { 1st insemination }\end{array}$} & \multirow{2}{*}{$\begin{array}{c}\text { Statistical } \\
\text { significance }\end{array}$} \\
\hline & & & & head & $\%$ & \\
\hline 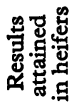 & $\begin{array}{l}\text { up to } 20 \\
21-30 \\
31-40 \\
41 \text { and more }\end{array}$ & & $\begin{array}{r}172 \\
120 \\
39 \\
108\end{array}$ & $\begin{array}{r}127 \\
90 \\
23 \\
56\end{array}$ & $\begin{array}{l}73.83 \\
75.00 \\
58.97 \\
51.85\end{array}$ & $\begin{array}{l}]^{P}>0.1 \\
{\left[\begin{array}{l}P \\
{[P}\end{array}-0.1\right.}\end{array}$ \\
\hline 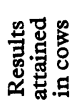 & $\begin{array}{l}\text { up to } 20 \\
21-30 \\
31-40 \\
41 \text { and more }\end{array}$ & *) & $\begin{array}{r}34 \\
46 \\
167 \\
97\end{array}$ & $\begin{array}{l}20 \\
26 \\
98 \\
49\end{array}$ & $\begin{array}{l}58.82 \\
56.52 \\
58.68 \\
50.51\end{array}$ & $\begin{array}{l}]_{P}>0.1- \\
]_{P}>0.1\end{array} \mid P>0.1$ \\
\hline
\end{tabular}

*) An assistant of the operator prepared the doses.

tion, with semen from one bull are to be seen, merely proves the known fact that the conception rate in breeders after a lst insemination may be influenced by by the operator.

The effect of the synchronized group size on the conception rate in breeders after a first insemination (Table 3 ) was also studied. With synchronized groups of heifers, containing up to 20 animals, 127 out of 172 inseminated conceived, i.e. $73.83 \%$. With groups of heifers numbering $21-30$ head, 90 animals out of 120 conceived after a first insemination, i.e. $75 \%$. In groups containing from 31-40 head, 23 conceived out of 39 , i. e. $58.97 \%$, and in groups of more than 41 heifers, 56 head out of 108 inseminated heifers conceived, i.e. $51.85 \%$.

The differences between the first two groups were not significant, in groups of 31-40 head, conception after a lst insemination was $16 \%$ smaller than in the group numbering $21-30$ head, and was at the limit of significance $(P<0.10)$. The difference between groups with $31-40$ head, and groups of over 41 head (58.97 and $51.85 \%$ ) was not significant, the difference between the group of $21-30$ ) head and the group of 41 heifers and more, was highly significant $(P<0.01)$ in favour of the group numbering $21-30$ head of synchronized heifers. One may therefore claim that in a synchronized group of heifers numbering 30 head, no decrease occurred in the conception rate after a first insemination. With larger 
groups conception rate decreased after inseminations carried out by a single operarator.

The effect of the size of the synchronized group of cows on the conception rate after a first insemination was not so striking as in heifers, for groups of 20,21-30, and $31-40$ cows conception rate of 58.82, 56.52, and $58.68 \%$ after a first insemination was found. Only in groups numbering 41 and more cows a decrease to $50.51 \%$ occurred. Compared to the previous group the difference was $8.0 \%$, and was not significant. In spite of lack of significant difference in conception between groups numbering 31-40 head, and 41 head and more, a decrease of $8 \%$ in conception suggests that the size of synchronized groups may adversely effect the results. One must take into account that in the experience gained during the synchronization of estrus in heifers it was agreed that an assistant should help the operator preparing the doses for insemination so that in the case of a larger number of groups of synchronized cows the procedure of insemination is accelerated, and the pellets thawed in accordance with the method of artificial insemination.

\section{Některé faktory ovlivňující výsledky zabřezávání krav a jalovic $\mathrm{v}$ řiji synchronizované syntetickým analogem $\mathbf{P G F}_{2}$ alfa cloprostenol}

Provedená sledování podílu plemeníka, práce inseminačního technika a vlivu velikosti synchronisované skupiny na výsledky zabřezávání plemenic po I. inseminaci v ŕ́iji synchronizované cloprostenolem u 21 skupin jalovic o celkovém počtu 469 ks a 12 skupin krav o celkovém počtu 350 ks prokázala, že:

1. Výsledky zabřezávání plemenic po $\mathrm{I}$. inseminaci $\mathrm{v}$ synchronizované řiji byly výrazně ovlivněny použitým býkem přiděleným připařovacím plánem. Po inseminacích plemenic provedených mrazeným semenem různých býků byly zjištěny statisticky vysoce významné rozdíly $\mathrm{v}$ zabřezávání po $\mathrm{I}$. inseminaci $(P<0,01)$.

2. Výsledky zabřezávání plemenic po I. inseminaci byly ovlivněny prací inseminačních techniků. Mezi jednotlivými techniky byly zjištěny až statisticky vysoce významné rozdíly $\mathrm{v}$ dosažené koncepci $(P<0,01)$.

3. Výsledky zabřezávání plemenic byly též výrazně ovlivněny velikostí synchronizované skupiny. Byl zjištěn pokles $\mathrm{v}$ zabřezávání po $\mathrm{I}$. inseminaci o $18 \%$ (na hranici statistické významnosti), když bylo $\mathrm{v}$ synchronizované skupinè více než 30 jalovic a statisticky výsoce významný pokles o $25 \%(P<0,01)$, když bylo ve skupině více než 40 jalovic, při inseminacích prováděných pouze jedním inseminačním technikem. U krav byl zjištěn pokles $\mathrm{v}$ zabřezávání po I. inseminaci o $8 \%$ ve skupinách s větším počtem plemenic než $40 \mathrm{ks}$.

Некоторые факторы, оказывающие влияние на результаты забеременения коров и телок в течке, синхронизированной синтетическим аналогом

$\mathrm{PGF}_{2}$ альфа клопростенол

Проведенные исследования доли племенника, работы техника по искусственному осеменению и влияния величины синхронизированной группы на результаты забеременения племенных маток после первого искусственного 
осеменения в течке, синхронизированной клопростенолом на 21 группе телок в общем количестве 469 голов и 12 групп коров в общем количестве 350 голов выявили, что:

1. Результаты забеременения племенных маток после 1 искусственного осеменения в синхронизированной течке находились под существенным влиянием определенного случным планом племенного быка. После искусственного осеменения племенных маток, проведенного замороженной спермой разных быков была выявлена большая разница выской статистической значимости в забеременении после 1 искусственного осеменения $(\mathrm{P}<0,01)$.

2. Результаты забеременения племенных маток после 1 искуственного осеменения соответствовали качеству работы отдельных техников, среди которых была установлена статистически весьма значимая разница в достигнутом заачтии $(\mathrm{P}<0,01)$.

3. Результаты забеременения племенных маток находились также под выразительным влиянием велиqины синхронизированной группы. Было установлено понижение забеременения после 1 искусственного осеменения на $18 \%$ (на пределе статистической значимости), когда в синхронизированной группе насчитывалось более 30 телок п статистически значимое понижение на $25 \%$ ( $2<0,01)$, когда в группе насчитывалось более 40 телок, при исћусственном осеменении, проводимом лишь одним техником. П коров было установлено понижение забеременения после 1 искусственного осеменения на $8 \%$ в группах с большим количеством племенных маток, превышающим 40 голов.

\section{References}

BINDER, D. - BOWLER, J. - BROWN, E. D. - CROSSLEY, N. S. - HUTTON, J. SENIOR, J. - SLATER, L. - WILKINSON, P. - WRIGHT, N. C. A.: 16-aryloxyprostaglandins a new class of potent luteolytic agent. Prostaglandins, 8, 1974: 87-90.

COOPER, M. J.: Control of oestrus cycles of heifers with a synthetic prostaglandin analogue. Vet. Rec., 95, 1974: 200-203.

COOPER, M. J. - FURR, B. J. A.: The role of prostaglandins in animal breeding. Vet. Rec., 94, 1974: $161-163$.

ELVING, L. - BRAND, A. - DE BOIS, C. H. W.: Oestrus synchronization and fertility in heifers treated with prostaglandin $F_{2}$ alfa. Tijdschr. Diergeneesk., 100, 1975: 758-762.

FULKA, J. - MOTLfK, J. - PAVLOK, A.: Synchronisace estrálního cyklu skotu analogem $\mathrm{PGF}_{2}$ alfa - Estrumate. Sborník ze symposia „,Rízení a kontrola reprodukce ve velkovýrobních podmínkách chovu skotu a prasat", VÚVL Brno, 1978: 211-216.

HAFS, H. D.: Ovulation control and release of hormones with prostaglandin $F_{2}$ alfa in cattle. Proc. VIIIth Int. Congr. Anim. Reprod. and A. I., Krakow, 1976, Plenary Papers: 17-27.

HAFS, H. D. - MANNS, J. G. - DREW, B.: Onset of oestrus and fertility of dairy heifers and suckled beef cows treated with prostaglandin $F_{2}$ alfa. Anim. Prod., 21, 1975: 13-20.

KUDLÁČ, E.: Synchronisace ř́je u skotu a ovcí. Ref. na symposiu na VŠV v Brně 1976.

KUDLÁĆ, E. - ELECKKO, J. - aj.: Veterinární porodnictví a gynekologie. 1. ed., Praha, SZN, 1977, $776 \mathrm{p}$.

KUDLÁC̆, E. - KOZUMPLIK, J. - HRIVNÁK, J. - VLČEK, Z. - VINKLER, A. VRTĚL, M.: Ovlivňování řízení reprodukčního cyklu u skotu. Project report VL-333-1-02/01, VŠV, Brno, 1979: 6-16.

KUDLÁC, E. - VRTĚL, M. - VINKLER, A.: Naše poznatky o terapeutickém použití syntetického analoga prostaglandinu cloprostenolu (spec. Estrumate) při některých poruchách plodnosti u skotu. Veterinářství, 29, 1979: 106-108.

KUDLÁC, E. - VRTĚL, M, - VINKLER, A.: Synchronisace řije u jalovic a krav cloprostenolem (ICI - 80996 - syntetický analog PGF $_{2}$ alfa). Vet. Med. Praha, 22, 1977: 655-664.

KUDLÁČ, E. - VRTĚL, M. - VINKLER, A.: Synchronisace řije u jalovic syntetickým analogem prostaglandinu. Sborník referátů ze symposia „Metody stanovení pohlavního cyklu hospodárských zviřat. Rízení a kontrola reprodukce ve velkovýrobních podmínkách chovu skotu a prasat", VUUVL Brno, 1978: 206-210. 
KUDLÁC, E. - VINKLER, A.: Synchronisace řije u krav ve velkovýrobních podmínkách, Veterinářství, 30, 1980: 12-14.

LAMING, G. E. - HAFS, H. D. - MANNS, J. G.: Hormonal control of reproduction in cattle. Proc. Br. Soc. Anim. Prod., 4, 1975: 71-78.

LAUDERDALE, J. W.: Effects of PGF $_{2}$ alfa on pregnancy and oestrus of cattle. J. Anim. Sci., 35, 1972: 246.

LAUDERDALE, J. W. - SEGUIN, B. E. - STELLFLUG, J. N. - CHEHAULT, J. R. THATCHER, W. W. - VINCENT, C. K. - LOYANCANO, A. F.: Fertility of cattle after PGF $_{2}$ alfa treatment. J. Anim. Sci., 38, 1974: 964-967.

LIEHR, R. A. - MARION, G. B. - OLSEN, H. H.: Effects of prostaglandin on cattle oestrus cycles. J. Anim. Sci., 35, 1972: 247-251.

LOUIS, T. M. - HAFS, H. D. - MORROW, D. A.: Intrauterine administration of prostaglandin $F_{2}$ alfa in cows. J. Anim. Sci., 38, 1974: 347-353.

MOORE, N. W. :The control of time of oestrous and ovulation and the induction of superovulation in cattle. Austr. J. Agric. Res., 26, 1975: 295-304.

PODANÝ, J. - STEJSKAL, J. - SVOBODA, M. - ŠfVARA, J. - ŽIŽLAVSKÝ, J. PETERKA, E.: Kontrola ř́je a ovulace u skotu pomocí syntetického analogu prostaglandinu $\left(\mathrm{PGF}_{2}\right.$ alfa). Veterinářství, 26, 1976: 485-486.

ROWSON, L. E. A. - TERVIT, H. R. - BRAND, A.: Synchronization of oestrus in cattle by means of prostaglandin $\mathrm{F}_{2}$ alfa. Proc. 7th Int. Congr. Anim. Reprod. and A. I., II, 1972: 865. 